\title{
Kpamkue сообиенuя
}

YLLK 577.37

(C) Г. П. Горбенкко, 1990

\section{ВЛИЯНИЕ ФОСФОЛИПИДОВ НА СВЯЗЫВАНИЕ БРОМТИМОЛОВОГО СИНЕГО МЕТГЕМОГЛОПИНОМ}

Исследовали соязывание сульфофталеинового красителя бролтилолового сннеео с метгеногльбинол при образовании белок-липионого колилекса. Ноказано, ито взиияодействие метгемоглобина с дипосомами из смеси фосфатио̆лтолина с кардиолипином сопровождается существенньми измененияни конфорнации белка.

Введение. В настоящес время в связи с развитлем концсцции структурной лабильности биомембран [1-3] особую актуальность приобретают исслсдования конформациониых перестроек их основных компонентов - белков и липидов. Одним из информативных подходов к выяснению механизмов модифицируюшего влияпия фосфолипидов на структурнос состояние белков является изучение сорбции красителей на поверхіости белковой молекулы [2]. Рансс было показано, что водорастворимые белкн, в частиости гсмоглобил, взаинодействуют с модельныии и ириродными мембранами с образованием комплсксов, стабилизируемых элсктростатичсскими и гидрофобными силами [4-7].

Цсль настоящсй работы заключалась в исследовании конформационых изменений метгемоглобина при образовании белок-липидного комтлекса с помощью анионного красителя бромтимолового синего ( $\mathrm{GTC})$.

Материалы и методы. В работе использовали фосфатидилхолин $(\Phi \mathrm{X)}$, кардиолипин (КЛ), фосфатидилсерин (ФС) («Бакпрепарат», Харьков), БТС («Реахим»). Метгемоглюбин полугали из оксигемоглобина, выделенного по методу [8], добавлснием $2 \mathrm{M}$ избытка феррицианида калия. Для приготовления липосом из смесей $\Phi \mathrm{X} \mathrm{K} Л$ или ФС липидную суспензию озвугивали 3 мин ири $4^{\circ} \mathrm{C}$ с помощью диспергатора УЗДН-1 на частоте 22 кГц. В работе использовали липосомы, полученные после осаждения миогослойных везикул центрифугированием 30 мип при $30000 \mathrm{~g}$. Концентрацию фосфолипицов в супернатанте определяли по неорганическому фосфату [9].

Реакцию комплексообразования проводили в $0,01 \mathrm{M}$ трис-HCl буфере, $\mathrm{pH}$ 7,4, при $25^{\circ} \mathrm{C}$ в течение 60 мин. Зависимости сорбции БТС от концентрации красителя получали при молярном соотношснии лнпид : белок $(\mathrm{L} / \mathrm{P}) \sim 20$, а влияние ионной силы ка связывание БТС нсследовали при $\mathrm{L} / \mathrm{P} \sim 50$. При таких соотношениях липид: белок бо́льшая часть молекул липида находится в связанном с белком состояпии, и в белоклипидной системе краситсль сорбируется, в основном, на поверхности белок-липидного комплекса. Оптическую плотность растворов измеряли на спектрофотометре СФ-46.

Результаты и обсуждение. Связывание БТС с мстгсмоглобнном и липосомами сопровождается уменьшением интенсивности спектральной полосы с максимумом при 615 нм. Как следует из таблицы, сорбция БТС на поверхности белка мало зависит от ионной силы, что согласуется с литературными данными о преимущественном вкладе гидрофобных взаимодействий в стабилизацию комплекса БТС с метгемоглобином [10]. Наряду с этим экранирование отрицательного заряда $\Phi С$ и КЛ при повышении концентрации соли приводит $\mathrm{K}$ усилению связывания красителя с липосомами. В белок-липидной системе метге- 
моглобин - ФХ: ҚЛ увеличение ионной силы практически не влияло на связывание БТС, а в системе метгемоглобин - $Ф \mathrm{X}: \Phi С$ приводило к усилснию сорбции красителя (таблица). Можно прсдположить, что при взаимодействии метгемоглобина с липосомами из $Ф Х$ и $Ф С$ структурное состояние белка существенно не изменяется, и при повышении ионной силы сорбция БТС в белок-липидной системе возрастает за

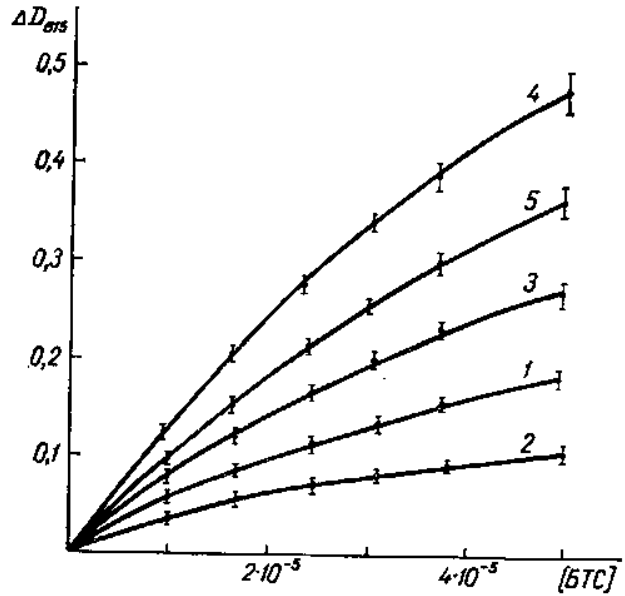

Зависимости изменения оптической плотности эри 615 нм от концентрации БТС: 1 метгемоглобин, $\quad 1 \cdot 10^{-5} \quad \mathrm{M} ; \quad 2-\Phi \mathrm{X}: \mathrm{KJ}$ $2 \cdot 10^{-4} \mathrm{M} ; 3-\Phi \mathrm{3}: \Phi \mathrm{C}, 2 \cdot 10^{-4} \mathrm{M} ; 4$-мет гемоглобин - $Ф \mathrm{X}: \mathrm{KJI} ; 5$-метгемогло$6 \mathrm{nH}_{\mathrm{H}}-\Phi \mathrm{X}: \Phi \mathrm{C}$

Plots of the optical density change at $615 \mathrm{~nm}$ vs the concentration of bromthymol biue: 1 methemoglobin, $1 \cdot 10^{-5} \mathrm{M} ; 2-$ phosphatidylcholine: cardiolipin, $2 \cdot 10^{-4} \mathrm{M} ; 3$ - phospha tidylcholine: phosphatidylserine, $2 \cdot 10^{-4} \mathrm{M}$ 4 - methemoglobin - PC : CL; 5-methemo globin - PC : PS

Относительное изменение оптинеской плотности БTC $\left(5 \cdot 10^{-5} \mathrm{M}\right)$ npu $615 \mathrm{~km}(\%)$

Relative change of the bromthymol blue $\left(5 \cdot 10^{-5} \mathrm{M}\right)$ optical density at $615 \mathrm{~nm}(\%)$

\begin{tabular}{|c|c|c|}
\hline Система & $\begin{array}{l}0.01 \mathrm{M} \\
\text { тpHc-HICl- } \\
\text { бypep, } \\
\mathrm{pH} 7,4\end{array}$ & $\begin{array}{c}0,01 \mathrm{M} \\
\text { трис-HCI } \\
6 \text { yqep, } \\
\text { pH 7.4, } \\
0,15 \mathrm{M} \\
\mathrm{NaCl}\end{array}$ \\
\hline
\end{tabular}

Метгемоглобин,

$4 \cdot 10^{-6} \mathrm{M}$

Липосомы,

$\Phi \mathrm{X}: \mathrm{KJ}(3: 1)$

$2 \cdot 10^{-1} M$

Липосомы,

$\Phi \mathrm{X}: \Phi \mathrm{C}(3: 1)$

$2 \cdot 10^{-4} \mathrm{M}$

Метгемоглобин -

$\Phi \mathrm{X}: \mathrm{KJ}(3: 1)$

Метгемоглобин -

$\Phi \mathrm{X}: \Phi \mathrm{C}(3: 1)$

$$
\begin{array}{ll}
17 \pm 3 & 19 \pm 4 \\
15 \pm 2 & 32 \pm 3 \\
35 \pm 4 & 49 \pm 3 \\
70 \pm 4 & 70 \pm 4 \\
53 \pm 4 & 63 \pm 3
\end{array}
$$

счет усиления связывания красителя с липосомами. Вместе с тем взаимодействие метгемоглобина с везикулами 13 ФХ и КЛ, по-видимому, сопровождается изменением конформации белка и возникновением дополнительных центров сорбции красителя, в состав которых, кроме непольрного фрагмента белковой молекулы, входят катионные группы [11]. Таким образом, в системе метгемоглобин-ФХ: КЛ в отличие от свободного белка увеличение ионной силы прнведет к снижению связывация красителя с белком н к усилепию связывания БТС с липосомами. Вероятно, взанмная компенсация вкладов этих двух факторов и обусловливает характер влияния ионной силы га сорбцио БТС в системе метгемоглобин - ФХ: ҚЛ.

Для оценки параметров связывания красителя с нативным метгемоглобином и метгемоглобином, образуюшим комплекс с фосфолипидами, использовали зависимости изменения оптической плотности при 615 нм $\left(\Delta D_{615}\right)$ от концентрации БTC (рисунок). При нсйтралыных pH раствор БTC представляет собой смесь кислой $\left(\mathrm{BTC}^{-}\right)$и целочной (БТС ${ }^{2-}$ ) форм [10]. Известно, что при взаимодействии БТС с метгемоглобином и фосфолипидами рКа красителя повышается $[10,14]$. В результате уменьшаетя концентрация БТС $2-$ и снижается интенсивность спектральной полосы с максимумом при 615 нм, характерной для двухзарядной формы красителя [10]. Изменение поглоцения $\Delta D_{615}$ связано с количеством сорбированного красителя [БТС]ахс соотношением [13]:

$$
\Delta D_{615}=\frac{[\mathrm{BTC}]_{\text {адс }}}{1+\left[\mathrm{H}^{+}\right] / K} \cdot \varepsilon,
$$

где $K$ - константа диссоциации формы БТС-; $\left[\mathrm{H}^{+}\right]-$концентрация ионов водорода; $\varepsilon=2,25 \cdot 10^{4} \mathrm{M}^{-1} \mathrm{~cm}^{-1}-$ молярный коэффициент экстинкции щелочной формы БТС при 615 нм [10]. 
Зависимость $\Delta D_{615}$ (БТС) для красителя, сорбированного на поверхности метгемоглобина, входящего в состав комплекса с фосфолипидами, получали следуюцим образом. Из величины $\Delta D_{615}$, характеризуюшей сорбцию красителя в белок-липидной системе (рисунок, кривые $4,5)$ вычитали $\Delta D_{615}$ красителя, связанного с немодифицированными липосомами (кривые 2, 3). Оказалось, что взаимодействие мстгемоглобина с липосомами из $\Phi Х$ и $Ф С$ практически не влияет на сорбцию БТС белком. Это согласуется с высказанным ранее предположением о том, что в данном случае образование белок-липидного комплекса не вызывает существенной перестройки структуры белка. Вместе с тем при связывании метгемоглобина с липосомами из $\Phi \mathrm{X}$ и КЛI сорбция БТС значительно возрастала. Параметры сорбции красителя - число участков связывания $(n)$ и константу ассоциации $\left(K_{a}\right)$ - оценивали по методу Скетчарда [2], определяя количество сорбированного БТС с помощью соотношения [1]. Для нативного метгемоглобина параметры связывания составляли: $n \sim 5 ; K_{\alpha} \sim 6 \cdot 10^{3} M^{-1}$ а для метгемоглобина, образующего комплекс с липосомами $(\Phi \mathrm{X}: \mathrm{KЛ}),-n \sim 20 ; K_{a} \sim 6 \mathrm{X}$ $\times 10^{3} \mathrm{M}^{-1}$. Из этих данных следует, что изменение топографии поверхности метгемоглобина при его взаимодействии с фосфолипидами приводит к увеличению числа центров связывания БТС в $\sim 4$ раза. Поскольку пгри нейтральных $\mathrm{pH}$ нативный гемоглобин связывается преимущественно с однозарядной формой БТС [10], весьма вероятно, что наблюдасмое усиление сорбции БТС обусловлено формированием центров, способных взаимодействовать как с однозарядной, так и с двухзарядной формами красителя $[11,12]$.

Таким образом, проведенное иссліедование сорбции БТС компонентами модельной белок-липидной системы показало, что взаимодействие метгемоглобина с липосомами из $\Phi \mathrm{X}$ и КЛ сопровождается существенной перестройкой структуры белка, тогда как образование комплекса между метгемоглобином и липосомами из ФХ и ФС не вызывает заметных изменений конформации белковой молекулы.

\section{INFLUENCE OF PHOSPHOLIPIDS ON BROMTHYMOL BLUE BINDING TO METHEMOGLOBIN}

G. P. Gorbenko

State University, Kharkov

$\mathrm{S}$ u $\mathrm{m} \mathrm{m}$ ary

The binding of bromthymol blue to methemoglobin during protein-lipid complex cormation has becn investigated. The methemoglobin interaction with liposomes consisting of phosphatidylcholine and cardiolipin mixture is shown to be followed by considerable changes of the protein conformation.

\section{СПИСОК ЛИТЕРАТУРЫ}

1. Конев C. B. Структурная лабильность биологических мембран и регуляторные процессы,- Минск : Наука и техника, $1987,-240$ с.

2. Лeвuн $C . B$. Структурные изменсния клеточных мембран.-Л.: Наука, 1976.$224 \mathrm{c}$.

3. Benga $G$. Interactions between components in biological membranes and their implications for membrane function // Progr. Biophys. Mol. Biol.- $1984 .-43$, N 3.P. $195-237$.

4. Interaction of different forms of hemoglobin with artificial lipid membranes/L. Bossi, S. Alema, P. Calissano, E. Marra//Biochim. et biophys, acta.-1975. - 375, N 3.P. $477-482$.

5. Shviro I., Zilber I., Shaklai $N$. The interaction of hemoglobin with phosphatidylserine vesicles // Ibid. - 1982.-687, N 1.- P. 63-70

6. Shaklai $H$., Yguerabide J., Ranney $H$. Classification and localization of hemoglobin binding sites on the red blood cell membranes // Biochemistry, $-1977,-16, \mathrm{~N} 25 \rightarrow$ P. 5593-5597.

окончание см. на з-й с. обложки. 
Окончание. Начало см. на с. $103-105$.

7. Нзучение взаимодействия метгемоглобина с фосфолипидными бислойными мембранами мстодом флуоресценции /И. П. Ушакова, И. А. Василенко, Г. А. Серебренникова, Р. П. Евстигнеева // Биоорг. химия.- 1981.-7, № 4.-С. 613-620.

8. Получение очищенного препарата гемоглобина и изучение его свойств / Г. Я. Розенберг, Е. П. Вязова, Г. Н. Иванова и др.// Пробл. гсматологии и переливания крови. - 1975 - 20, № 11.- С. $25-29$.

9. Кейтс M. Техника липидологии.-М. : Мир, 1975.-322 с.

10. The interaction of bromthymol blue with hemoglobin and its effect on the oxygen equilibrium /E. Antonini, J. Wyman, R. Moretti, R. A. Flanelli// Biochim. et biophys. acta.- 1963.-71, H 1.- P. 124-138.

11. Варечкая Т. В., Рябоконь Р. М. О взаимодействии белков с анионами бромтимолового синего // Укр. биохим. журн.- 1960.-32, № 4.-С. 507-515.

12. Белицер B. A., Варецкая T. В. Связывание красителей белками в нативном, денатурированном и химически модифицированном состоянии // Там же. $1959 .-31$, № 2.-C. $171-185$.

13. Colonna R., Dell'Antone P., Azzone C. Binding changes and apparent $\mathrm{pK}$ shifts of bromthymol blue as tools for mitochondrial reactions // Arch. Biochem. and Biophys.1972.-151, N 1.- P. 295-303.

14. Mashimo T., Uede I. Hydrophilic region of lecithin membranes studied by bromthymol blue and effects of an inhalation anesthetic, enflurane//Proc. Nat. Acad. Sci. USA.1979.-76, N 10.-P. 5114-5118. 